\title{
Optical biochemical and chemical sensors: Europt(r)ode $X$
}

\author{
Jiř́i Homola
}

Published online: 10 September 2010

(C) Springer-Verlag 2010

This year, the European Conference on Optical Chemical Sensors and Biosensors (Europt(r)ode) celebrated its 10th anniversary. The Europt(r)ode series was initiated by Otto S. Wolfbeis in 1992 and over the last two decades has realized his vision of providing researchers working on various types of optical chemical and biological sensors with a specialized conference to foster development in the field and to promote international collaboration. After the success of Europt(r)ode I in Graz in 1992, Europt(r)ode has continued as a biennial conference in Florence (chaired by A. M. Scheggi), Zurich (chaired by U. Spichiger-Keller), Münster (chaired by K. Camman), Lyon (chaired by P. R. Coulet), Manchester (chaired by R. Narayanaswamy), Madrid (chaired by G. Orellana), Tuebingen (chaired by G. Gauglitz) and Dublin (chaired by B. D. MacCraith and C. McDonagh). In 2010, Europt(r)ode $\mathrm{X}$ was held in Prague, 28-31 March, and attracted more than 250 participants from 27 countries.

During the almost two decades of its existence, Europ$t(r)$ ode has become a major scientific meeting on optical chemical sensors and biosensors attracting scientists not only from Europe, but from across the globe. Because of the multidisciplinary nature of the field, Europt(r)ode has always brought together a diverse audience including scientists and engineers in physics, chemistry and biology. Their engaging discussions have stimulated interdisciplinary and international collaborations and helped to shape scientific

Published in the special issue Optical biochemical and chemical sensors (Europtrode X) with Guest Editor Jiří Homola.

J. Homola $(\bowtie)$

Institute of Photonics and Electronics,

Academy of Sciences of the Czech Republic,

Chaberska 57,

18251 Prague 8, Czech Republic

e-mail: homola@ufe.cz schools from which several generations of $\mathrm{PhD}$ students have graduated.

The scientific program of Europt(r)ode X comprised a total of 230 scientific presentations covering various aspects of research and development of optical chemical sensors and biosensors. These presentations included 5 plenary lectures, 10 invited lectures, 34 contributed oral presentations and 181 poster presentations. The plenary lectures were given by María C. Moreno Bondi (University Complutense, Spain), Andrew deMello (Imperial College, UK), Teri W. Odom (Northwestern University, USA), Michael J. Sailor (University of California, USA) and Otto S. Wolfbeis (University of Regensburg, Germany). The plenary and invited lectures were selected to cover traditional topics as well as emerging areas, such as optofluidics for chemical analysis, nanoparticles and nanostructures for optical biosensing, silicon photonics biosensors, photonic fibres for label-free biosensing, artificial receptors and polymers for label-free biosensing in complex media. The oral and poster presentations fell into six main thematic areas. The largest number of presentations (nearly 25\%) were concerned with the topic Optical platforms and methods for sensing. This high percentage documents the pivotal role that optics plays today in optical chemical sensing and biosensing and a high number of new original developments realized in the last few years. Moreover, new optical solutions to sensing were also presented under the thematic area Multisensors and sensor arrays, which accounted for $8 \%$ of the presentations. Advances in the development of new receptors were less represented at Europt(r)ode $\mathrm{X}$ with less than $5 \%$ of presentations submitted for the thematic area Biological and synthetic receptors. Europt(r)ode $\mathrm{X}$ testified to the growing importance of nanophotonics and nanomaterials in optical sensing with nearly $17 \%$ of the presentations submitted to 
the thematic area Nanostructures and nanomaterials for sensing. Application-oriented sessions attracted nearly a half of the presentations. The conference session on Chemical sensing included $22 \%$ of the presentations and covered mainly applications of optical sensors for the detection of gases and measurements of $\mathrm{pH}$. The thematic area Biological sensing (23\%) comprised presentations covering a wide variety of biodetection applications targeting disease biomarkers, food contaminants, pathogens and toxins, environmental pollutants, explosives, etc. The scientific program was complemented by a technical exhibition involving suppliers of scientific equipment, research companies and a publisher. The program of Europt(r)ode $\mathrm{X}$ and other details are still available at http://www.europtrodex.eu/.

Considering the number of papers presented at Europ$t(r)$ ode $X$, the number of papers accepted for publication in this special issue is modest. Apparently, authors only rarely find the time required to write a critical review, and many interesting presentations covering the latest research results were not ready to be published as a full paper in such a short time after the conference. However, I would like to thank all the authors for their contribution to this special issue as well as the editorial staff of Analytical and Bioanalytical Chemistry for their help with its preparation.

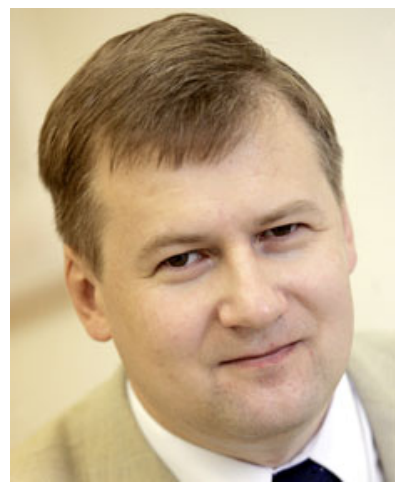

Jiří Homola is Head of Photonics Division and Chairman of the Department of Optical Sensors at the Institute of Photonics and Electronics, Prague (Czech Republic). He also is Affiliate Professor at the University of Washington, Seattle (USA), Adjunct Professor at the University of Oulu (Finland), a member of the editorial board of Sensors and Actuators $B$ and Associate Editor of Journal of Sensors. He is also a member of the permanent steering committees of the Advanced Study Course on Optical Chemical Sensors and the Europt(r)ode conference series. His research interests are in photonics and biophotonics with emphasis on optical sensors and biosensors. 